\title{
BUILD-UP FORMATION IN AN INDUCTION CHANNEL FURNACE
}

\author{
NASTANEK NASEDLINE V INDUKCIJSKI KANALNI PEČI
}

\author{
Marica Prijanovič Tonkovič ${ }^{1}$, Jakob Lamut ${ }^{2}$ \\ ${ }^{1}$ Short-cycle, Higher Vocational College, Mechanical Engineering, Šegova 112, 8000 Novo Mesto, Slovenia \\ ${ }^{2}$ University of Ljubljana, Faculty of Natural Sciences and Engineering, Aškerčeva cesta 12, 1000 Ljubljana, Slovenia
}

Prejem rokopisa - received: 2019-09-30; sprejem za objavo - accepted for publication: 2019-12-01

doi:10.17222/mit.2019.233

\begin{abstract}
Iron foundries use induction channel furnaces as an aggregate for melt holding and homogenization. But during operation, build-up grows in the induction channel, it reduces the flow of the melt through the channel, thus decreasing its effectiveness. This paper presents the results of a build-up analysis and discusses its formation. The build-up is composed of several mineral phases, like spinel, forsterite and melilite. The build-up also contains entrapped grey cast iron and products of desulphurization and inoculation. The microstructure of the entrapped cast-iron inclusions varies from hypoeutectoid cast iron to cast iron with dendrites of transformed austenite charged in the graphite eutectic. Complex sulphides are formed next to the cast iron with flaky graphite.
\end{abstract}

Keywords: induction channel furnace, cast iron, build-up, mineral composition

V livarnah uporabljajo kot agregat za shranjevanje in homogenizacijo litine indukcijske kanalne peči. V kanalu induktorja nastajajo med obratovanjem nasedline, ki zmanjšujejo pretok taline skozi kanal induktorja. V članku so prikazani rezultati raziskave sestave nasedline, nastale med obratovanjem v kanalu induktorju. Nasedlina je sestavljena iz spinela, forsterita, melilita, produktov razžveplanja ter cepljenja litine. V nasedlini so tudi delci sive litine različnih velikosti in oblik. Mikrostruktura ujete litine se spreminja od feritno-perlitne mikrostrukture do litine $\mathrm{z}$ dendriti transformiranega avstenita, $\mathrm{v}$ osnovi grafitnega evtektika. Ob litini z grafitnimi lamelami se pojavljajo tudi sulfidi kompleksne sestave.

Ključne besede: indukcijska kanalna peč, induktor, nasedlina, mineralna sestava

\section{INTRODUCTION}

Cupola or induction melting furnaces are used for melting cast iron. Working with induction furnaces is relatively easy and they do not need a lot of working space. Induction channel furnaces are normally used for melt holding before casting, because of their high capacity (several tens of tons) that ensures a stable chemical composition of the castings. The molten cast iron flows from the cupola furnace through a syphon into the induction channel furnace. The induction channel furnace is intended for holding and homogenizing the melt. Constant temperature has to be maintained for casting. ${ }^{1,2}$ Channel induction furnaces are commonly used as a holding and superheating unit for higher-melting-point alloys such as cast iron.

The channel induction furnace is a simple transformer where the primary induction coil is wound around an iron core and the secondary component is a refractory-lined steel shell that contains the molten metal (Figure 1). The refractory-lined steel shell is the crucible with the primary inductor attached under it, so that the iron melt is held at high temperatures and constantly stirred through the channel into the crucible. ${ }^{3,4}$ The electromagnetic field in the furnace causes highly

*Corresponding author's e-mail:

marica.prijanovic@sc-nm.si (Marica Prijanović Tonković) turbulent mixing, the melt circulates due to Lorentz forces. ${ }^{5-7}$

The channel has the form of the letter $\mathrm{U}$, which means that at one end the melt flows from the crucible into the channel (i.e., inlet channel), while on the other end, the heated melt is returned to the crucible (i.e., outlet channel). While the furnace is working it is important that the level of the melt is high enough so that the slag does not become entrapped during circulation.

The induction channel is usually replaced every year due to the build-up formation. The build-up formation and composition depend on the quality of the primary melt from the melting furnace, melt temperature, slag composition and the use of nodulators and inoculants. ${ }^{8}$

The melt is heated up in the induction channel, so a constant melt flow is needed to prevent local overheating. ${ }^{6,9,10}$ Build-ups not only narrow the channel

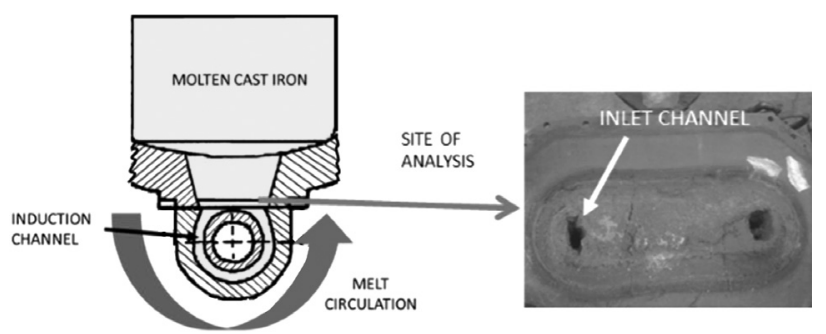

Figure 1: Induction channel furnace 
radius and reduce the melt flow, but also reduce the power of the inductor.

The composition of the build-up that formed during the operation of the induction channel furnace is described in this paper.

\section{EXPERIMENTAL PART}

The investigated build-up occurred in a 50-ton induction channel furnace at a foundry that typically produces grey cast iron $(3.45 w / \% \mathrm{C}, 1.93 w / \% \mathrm{Si}, 0.62$ $w / \% \mathrm{Mn}, 0.08 w / \% \mathrm{~S}, 0.11 w / \% \mathrm{Cr})$ and occasionally ductile (nodular) cast iron. The channel was replaced after a year of operating, which means around 40,000 tons of cast iron was processed. The cupola is charged with scrap iron, recycled cast iron, silicon carbide, ferromanganese, coke and limestone as a slag-forming additive. When the ferrous melt is produced, it is transported out of the cupola furnace into the induction channel furnace. Occasionally, there is some slag present on the melt, it is removed using a slag-skimming agent (68-75 w/\% $\mathrm{SiO}_{2}, 10-12 w / \% \mathrm{Al}_{2} \mathrm{O}_{3}, 1-2.5 w / \% \mathrm{Fe}_{2} \mathrm{O}_{3}$, $1.5-2 w / \% \mathrm{CaO}, 0.2-1.5 w / \% \mathrm{MgO}, 3.2-4.5 w / \% \mathrm{~K}_{2} \mathrm{O}$, $2.8-4.5 w / \% \mathrm{Na}_{2} \mathrm{O}$ ), to prevent refractory degradation.

The crucible of the channel furnace is lined with insulation and aluminate bricks stamped with an alumina-based mass (with 4 w/\% $\mathrm{SiO}_{2}$ ), while the induction channel refractory material is a magnesia-based mass (86 $w / \% \mathrm{MgO}, 13 w / \% \mathrm{Al}_{2} \mathrm{O}_{3}+\mathrm{TiO}_{2}$ ). The furnace inductor power and power factor are monitored to detect excessive build-up formation (Figure 2). The power factor is kept below 0.6 and is defined as:

$$
\cos \varphi=\frac{\text { active power }}{\text { apparent power }}
$$

In our case the factor $\cos \varphi$ reached a critical value after 12 months, as shown in Figure 2.

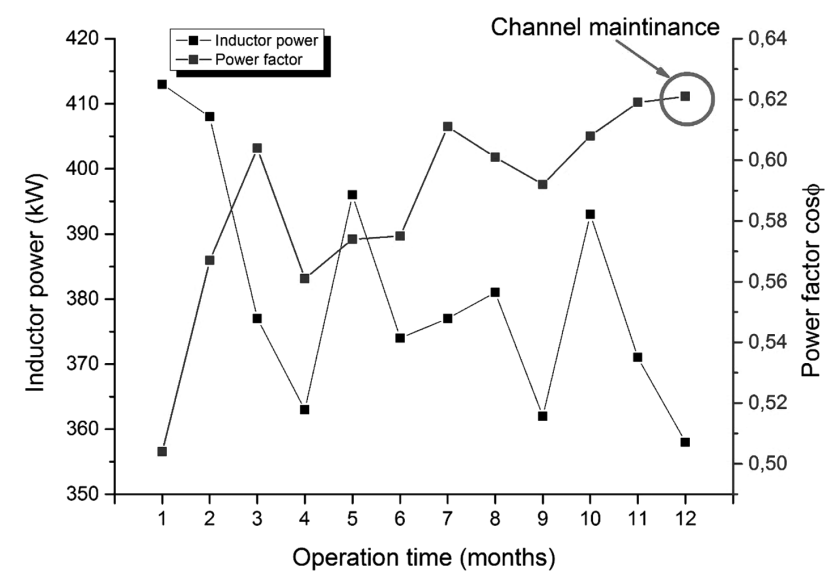

Figure 2: Inductor power and power factor during operation

\section{MATERIALS AND METHODS}

The microstructure was observed with a Nikon Microphot FXA light microscope and a SEM Jeol 5610 scanning electron microscope.

A sample of a build-up produced in the inductor channel after a year of running the furnace was taken.

\section{RESULTS}

Figure 3 shows part of magnesite refractory material that has build-up composed of oxide compounds and individual particles of cast iron. The build-up is composed of three different-coloured layers (Figure 3). Light colours on the right-hand side present the sintered layer of magnesium refractory material that continues into the darker layer and it is then followed by build-up of lighter colour.

Figure 4a shows the microstructure of the light layer (Figure 3) of the sintered refractory material. It is composed of grains of periclase.

The process of magnesite refractory sintering in the inductor channel is carried out with induction heating of an iron core at about $1200{ }^{\circ} \mathrm{C}$. Scale (iron oxide) on the surface of the iron core reacts with magnesium oxide and magnesium ferrite $\mathrm{MgO} \cdot \mathrm{Fe}_{2} \mathrm{O}_{3}$ is formed, as seen in Figure 4b (magnesium ferrite (white) in magnesium oxide - periclase). The composition of magnesium ferrite in periclase was determined with the EDS analysis $w / \%$ (16.4 MgO, 78.8 $\mathrm{Fe}_{2} \mathrm{O}_{3}$ and $4.8 \mathrm{Al}_{2} \mathrm{O}_{3}$ ). The sintered refractory mass also contains forsterite $2(\mathrm{MgO}, \mathrm{FeO})$. $\mathrm{SiO}_{2}\left(52 w / \% \mathrm{MgO}, 44 \mathrm{w} \% \mathrm{SiO}_{2}\right.$ and $\left.4 w / \% \mathrm{FeO}\right)$.

Build-up starts forming on the surface of the sintered refractory material in the induction channel that is in contact with the melt. The build-up that formed during melt-refractory interaction also contains inclusions of cast iron. The entrapped cast-iron inclusions are both round and irregular shapes that are embedded in the

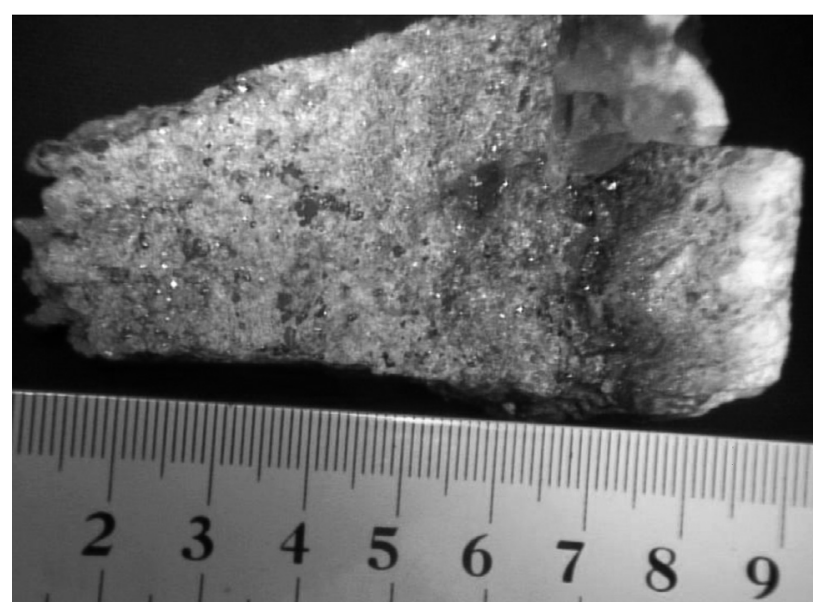

Figure 3: Build-up on refractory material in the furnace inductor channel 


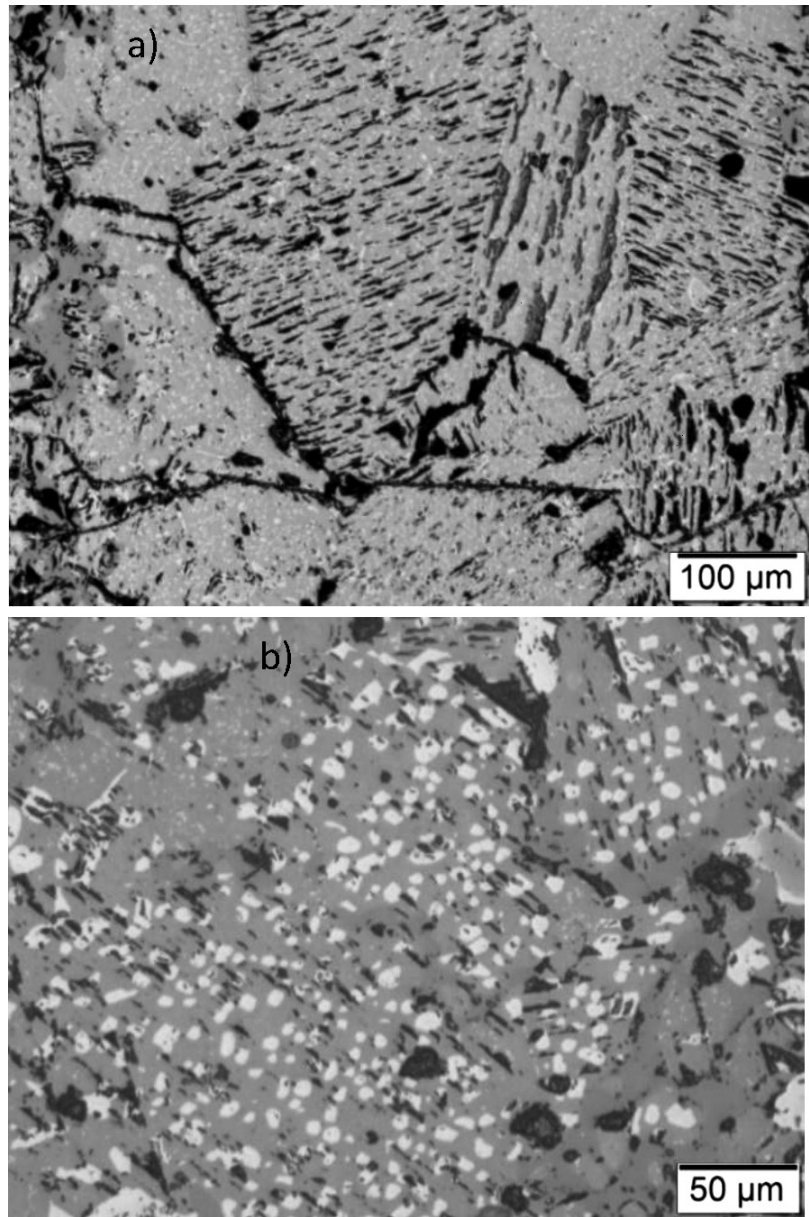

Figure 4: a) microstructure of the grains of periclase in the channel refractory, b) microstructure of magnesium ferrite

oxide matrix that conglomerated on the refractory material (Figure 5).

Further investigations revealed the entrapped castiron inclusions with flaky graphite and pearlitic-ferritic matrix (Figure 6a) and hypoeutectic cast iron with

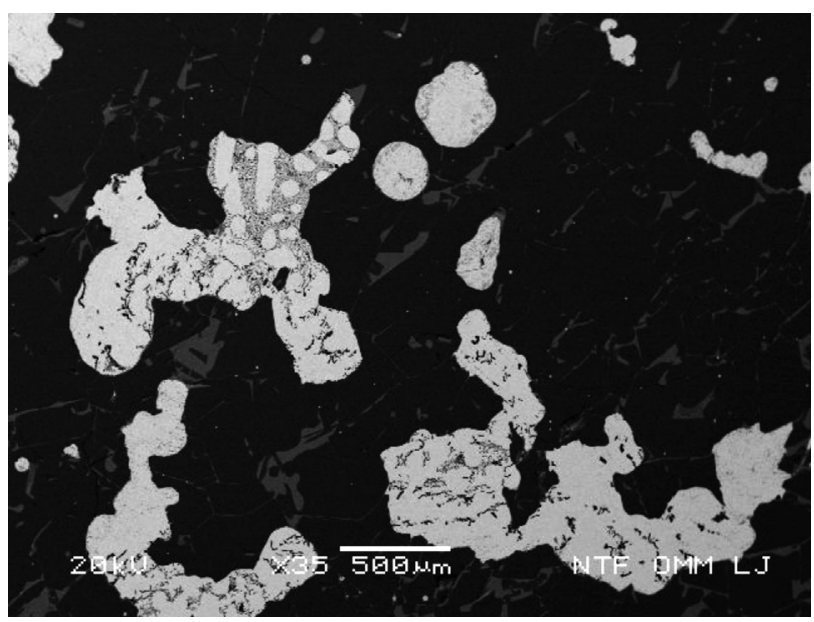

Figure 5: Inclusions of iron in build-up formed on the refractory material on the inductor channel (polished)
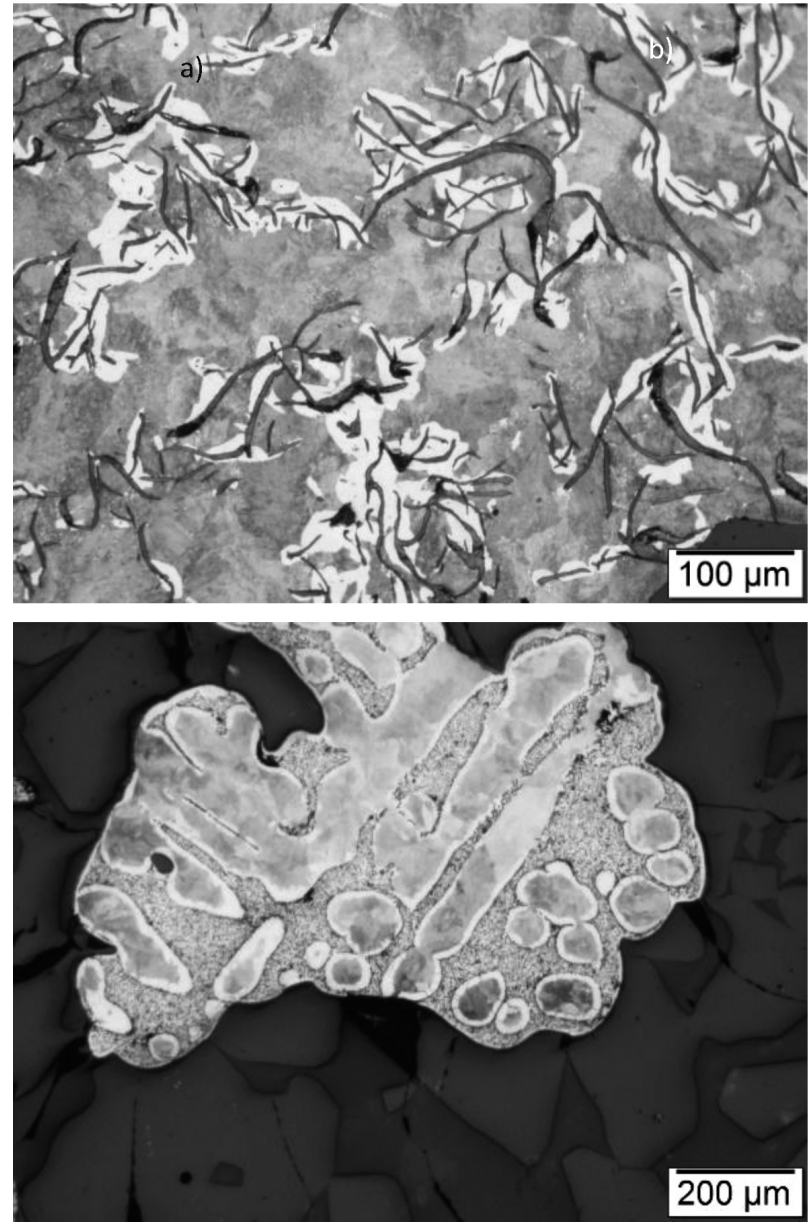

Figure 6: a) microstructure of entrapped cast-iron inclusions in build-up, pearlite, ferrite and flaky graphite b) hypoeutectic composition, dendrites of transformed austenite pearlite and graphite eutectic (alpha $+\mathrm{C}_{\text {graphite }}$ ), etched with nital

primary austenite dendrites (now pearlite) and graphite eutectic (alpha $+\mathrm{C}_{\text {graphite }}$ ) (Figure 6b). The primary austenite dendrites are surrounded with light areas of ferrite, because the cementite disintegrated during slow

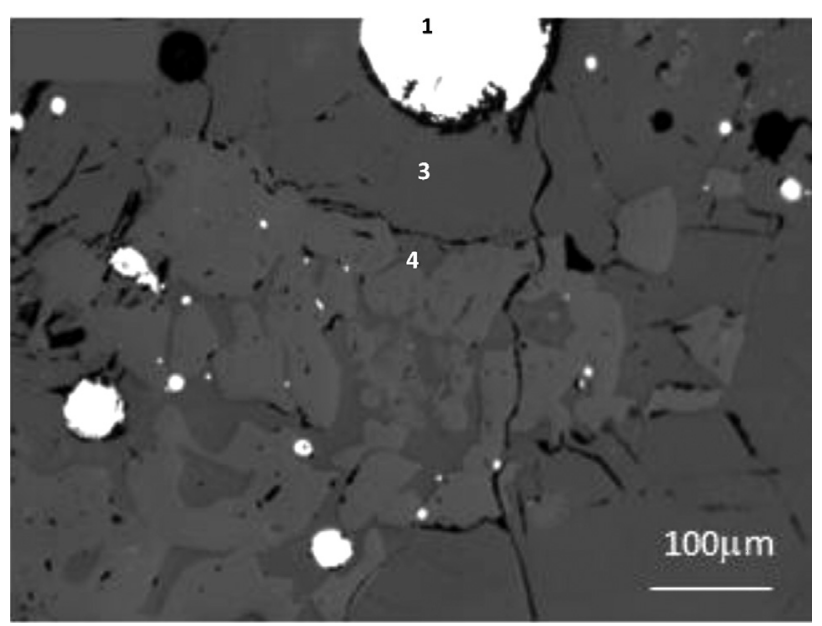

Figure 7: Build-up with 1, entrapped cast iron, 2 forsterite, 3 spinel, and 4 melilite 


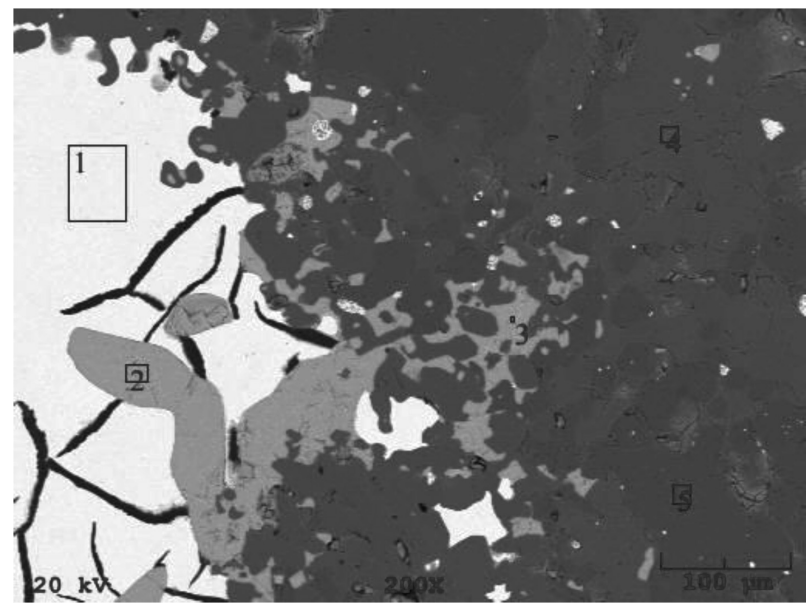

Figure 8: Build-up with 1, cast iron and 2 sulphide and forsterite

cooling next to the eutectic graphite (the carbon diffused towards eutectic graphite).

The build-up is composed of different minerals and entrapped cast-iron inclusions, as seen in Figure 7. The larger entrapped inclusion of cast iron (no. 1) is surrounded by forsterite (no. 2) $2 \mathrm{MgO} \cdot \mathrm{SiO}_{2}$. EDS analysis also revealed it contains $1.1 \mathrm{w} / \% \mathrm{CaO}$. The spinel phase $\mathrm{MgO} \cdot \mathrm{Al}_{2} \mathrm{O}_{3}$ is indicated with no. 3 .

The phase between the spinel crystals is melilite (no. 4) with an average composition of $\mathrm{CaO}-27.8, \mathrm{MgO}-6.9$, $\mathrm{SiO}_{2}-45.4, \mathrm{Al}_{2} \mathrm{O}_{3}-15.2, \mathrm{BaO}-4.4$ in $w / \%$. Melilite is a solid solution of $2 \mathrm{CaO} \cdot \mathrm{SiO}_{2} \cdot \mathrm{Al}_{2} \mathrm{O}_{3}$ and $3 \mathrm{CaO} \cdot \mathrm{MgO}$. $2 \mathrm{SiO}_{2}$; it also has the lowest melting point among the analysed phases and was also the last to solidify.

The build-up, surprisingly, also contains sulphides. Figure 8 shows an example of an entrapped cast-iron inclusion with flaky graphite and sulphides that are partially engulfed by the metallic phase and partially by the oxide phase. EDS analysis revealed that the sulphide is composed of $18 w / \% \mathrm{Mg}, 25 w / \% \mathrm{Mn}, 3 w / \% \mathrm{Fe}$, $2 w / \% \mathrm{Ce}$ and $52 w / \% \mathrm{~S}$. The oxide phase is mainly fosterite $2 \mathrm{MgO} \cdot \mathrm{SiO}_{2}$.

\section{DISCUSSION}

$\mathrm{SiO}_{2}, \mathrm{Al}_{2} \mathrm{O}_{3}, \mathrm{CaO}$ and $\mathrm{MgO}$ are present in the slag of the cupola furnace, in the refractory material of the furnace crucible and also in the slag-skimming agent. Calcium oxide also enters the cast iron during the desulphurization with calcium carbide. In spite of slag skimming, some of it still gets inside the furnace crucible.

The melt level in the crucible of the induction channel furnace changes during the process of casting. Changes of the melt level depend on the speed of pouring from the furnace to the ladle and melt flow from the cupola furnace. At weekends the level of molten iron in the furnace is the lowest, because the production stops.
When the melt is poured out of the induction furnace into the casting ladle or when the syphon is being cleaned, the crucible tilts and if the level of the melt is low, these conditions enable the slag to enter the inductor channel.

Vortexes occur during continuous heating and circulation of the melt, when the melt level is low or when the crucible is tilted. Because of the turbulent melt movement in the inductor channel the slag comes into contact with the magnesium oxide refractory. High-melting-point phases like spinel, forsterite and melilite are formed at the phase border between the refractory, the melt and the slag. Due to this high melting point they sinter and agglomerate on the refractory material and form the buil-up. The iron melt is also entrapped in the process. After the spinel and forsterite formation, the concentration of calcium oxide rises in the rest of the slag, thus enabling melilite formation. Melilite contains $2 w / \%$ to $3 w / \%$ of barium oxide that enters the melt with inoculation. Calcium manganese sulfide $(\mathrm{Ca}, \mathrm{Mn}) \mathrm{S}$, the product of desulphurization of cast iron. Even complex sulfides $(\mathrm{Mg}, \mathrm{Mn}, \mathrm{Ce}) \mathrm{S}$ are formed from the graphite nodulator agent for ductile cast iron. $\mathrm{Mg}$ and $\mathrm{Ce}$ react with oxygen and sulphur in ferrous melts. ${ }^{11,12}$

\section{CONCLUSIONS}

The channel induction furnace's operation was interrupted by the channel build-up formation, the build-up was analysed and its formation discussed. The build-up formation starts before the furnace operates with the iron melt - during the magnesia refractory sintering. The iron core that is used for sintering magnesium oxide refractory oxidises and forms magnesium ferrite. When the iron melt is introduced, the slag and additives react with the refractory. An oxide build-up forms and grows in the induction channel as the result of the melt-slag-additive-refractory reactions. As the oxide mass grows it entraps the iron melt that forms cast iron inclusions. The build-up consists of several minerals: spinel, forsterite and melilite as well as products of desulphurization and inoculation.

\section{REFERENCES}

\footnotetext{
${ }^{1}$ Induktions-Rinnenöfen zum Warmhalten von Gusseisen, https://www.otto-junker.com/de/produkte-technologien/anlagen-fuergusseisen-stahl/induktions-rinnen-warmhalteoefen/, 19. 07. 2018

${ }^{2}$ F. Nosan, Indukcijska kanalna peč v livarni sive litine, Livarski vestnik, 2 (1985) 59-62

${ }^{3}$ C. Eckenbach, W. Spitz, The Use of Channel-type Inductors and Coreless Inductors in the Non-Ferrous Metal Industry, World of Metallurgy - Erzmetall 66 (2013), 2, 93-101

${ }^{4}$ Channel induction furnaces, http://www.atlasfdry.com/inductionfurnaces.htm, 10. 10. 2018

${ }^{5}$ M. T. Kumar, Metal Melting Furnaces, RRCE, B’lure Karnataka, India, https://www.slideshare.net/ThanujKumarM/metal-meltingfurnaces-by-thanuj, 16. 10. 2018
} 


\section{PRIJANOVIČ TONKOVIČ, J. LAMUT: BUILD-UP FORMATION IN AN INDUCTION CHANNEL FURNACE}

${ }^{6}$ E. Baake, A. Jakovics, Untersuchung und Verbesserung des Betriebsverhaltens von Induktionsrinnenöfen durch Anwendung von Computersimulation, Giesserei, 100 (2013), 30-34

${ }^{7}$ H. H. Netzel, Induction-Furnace-Handbook, IES, Induktion Experience Service, Witten, 2004, 49

${ }^{8}$ R. L. Williams, Mechanism and Control of Buildup Phenomenon in Channel Induction and Cleveland, Ohio USA, Ductile Iron, 1 (2007) 44-55

${ }^{9}$ M. Langejürgen, M. Kirpo, A. Jakovics, E. Baake, Numerical Simulation of Mass and Heat Transport in Induction Channel Furnaces, International Scientific Colloquium Modelling for Electromagnetic Processing Hannover, October (2008) 35-40, http://www.modlab.lv/ publications/mep2008/pdfs/47-52.pdf, 05. 11. 2019
${ }^{10}$ U. Lüdtke, N. Tran, Numerische Simulation der Frequenzabhängigkeit des Wirkungsgrades bei Induktionsrinnenöfen im Niederfrequenzbereich, Elektrowärme international, 4 (2014) 65-68, doi:10.1088/1757-899X/355/1/012012

${ }^{11}$ J. Lamut, J. Falkus, B. Jurjovec, M. Knap, Influence of inclusions modification of nozzle clogging. Archives of metallurgy and materials, 27 (2012) 1, 319-324, doi:10.2478/v10172-012-0029-0

${ }^{12}$ B. Šuler, J. Burja, J. Medved, Modification of Non-Metallic Inclusions with Rare-Earth Metals in 50CrMoV13-1 Steel, Mater. Tehnol., 53 (2019) 441-447, doi:10.17222/mit.2018.271 